v. 13, n. 6

Vitória-ES, Nov.-Dec. 2016

p. 260 - 290 ISSN 1808-2386

DOI: http://dx.doi.org/10.15728/bbr.2016.13.6.5

\title{
What Factors Lead Companies to Adopt Social Media in their processes: Proposal and Test of a Measurement Model
}

\author{
Jozé Braz de Araújo ${ }^{\dagger}$ \\ Nove de Julho University - UNINOVE \\ Silvia Novaes Zilber ${ }^{\Omega}$ \\ Federal University of $A B C-U F A B C$
}

\begin{abstract}
The objective of this study was to understand which factors lead companies to use social media to achieve results. For that, a theoretical model was proposed and tested. Data was collected using a survey of 237 companies. In the analysis we analysis used the structural equation modeling technique. The results show that the social media relative advantage and its observability were important factors to social media organizational adoption. We also found that big companies with more formalized organizational structure (OS) tend to adopt social media more than small ones with no formal OS. The companies studied showed strong organizational disposition for innovation adoption.
\end{abstract}

Keywords: Social media. Innovation. Social media organizational adoption model.

Received on 09/09/2015; Reviewed on 09/29/2015; Accepted on 10/20/2015; Divulgued on 11/01/2016.

*Author for correspondence:

†. Doctor in Administration.

Link: Nove de Julho University - UNINOVE.

Address: Comendador Roberto Ugolini Street, 549, São Paulo

- SP - Brazil.

E-mail: jbraz67@gmail.com
$\Omega$ Doctor in Administration by the FEA-USP; Engineer by the POLI-USP.

Link: Universidade Federal do ABC - UFABC; Centro dee Engenharia, Modelagem e Ciências Sociais Aplicadas - CECS.

Address: UFABC - Campus São Bernardo

Arcturus Street, 3 - Jardim Antares - São Bernardo do Campo - SP

- Brazil. Cep: 09606-070.

E-mail: silviazilber@gmail.com ou silvia.zilber@ufabc.edu.br

Note from the Editor: This paper was accepted by Bruno Felix. 


\section{INTRODUCTION}

ocial media promote a new form of communication between people and between people and companies that use tools and services available on the Internet, such as Facebook, LinkedIn, Twitter, Blogger, Wikipedia and YouTube. The use of these tools can significantly alter the relationship between the company and its suppliers, customers, employees and stakeholders, as well as the general public which has no direct relationship with the organization, but want or intend to have such a relationship as job candidates, potential customers or suppliers and the press. According to Ngai et al. (2015) "the advent of social media has substantially changed the manner in which many people, communities and/or organizations communicate and interact".

According to Safko (2010), social media are formed by countless sites that promote communication and conversations among millions of people, but they are also used to reach targeted audiences. The means of communication involved in the term social media combine several features that compose social media platforms, including the publishing and sharing of content, such as texts, videos, photos and music. Social media also includes casual, social or mass multiplayer games; commerce, involving the review of purchases, virtual store recommendation and the sharing of purchases; event locations and location guides; and personal, professional or informal social networks (CAVAZZA, 2012).

According to data from the Organization for Economic Cooperation and Development (OECD) in its 2012 report about Internet Economy, on average, 96\% of its sample firms in selected countries used the Internet and 69\% had their own websites in 2011. Additionally, an increasingly high percentage of individuals is using the Internet, especially social media, for communicating, shopping, learning, social networking, banking, and many other functions (OECD, 2012). According to OECD (2012), in Europe, nearly half of all employed persons are connected to the Internet at work.

In many parts of the world, companies are embracing social media as a solution to various issues characterized as problematic, such as the improvement of customer relations (BRYNJOLFSSON, 2011), the promotion of new products (CHAUHAN, 2011; FURLAN, 2011; FOLDEES, 2012), the dissemination of information to employees (Safko 2010) and employee recruitment (FOLDEES, 2012).

These examples show how social media can be understood as an organizational innovation, as prescribed by the Oslo Manual (OECD 2005), since it states that if the 
innovation includes the first use of new organizational methods in business practices, workplace organization or external relations of the company, this innovation can be considered as an organizational innovation.

According to He et al. (2013), the companies are using social media in order to gain business values, especially some marketing ones such as increasing customer loyalty and retention, improving customer satisfaction, among others. Culnan et al. (2010) also argue that big companies can gain value from social media, but they state that they have to develop implementation strategies based on three elements (mindful adoption, absorptive capacity and community building). He et al. (2013) also affirm that innovation is a typical activity supported by social media.

The very act of using social media as a tool in order to add business value can be considered as an innovation adoption. In this sense, in our study, innovation (social media) adoption refers to the decision of individuals or an organization to make use of an innovation (ROGERS, 1983). In fact, Zhu et al. (2006) state that innovations that have been enabled by the Internet are a primary driver of industrial productivity; however, unless these promised innovations be widely adopted, the benefits will be curtailed. In their study, they tried to understand how technology readiness, technology integration, firm size, global scope, managerial obstacles, competition intensity, and regulatory environment influence e-business assimilation at the firm level. They found that competition affects the adoption in the beginning; they also found that large firms have resource advantages at the beginning, but they have to overcome structural inertia in later stages. The last finding of Zhu et al. (2006) refers to the fact that economic environments matters: regulatory environment plays a more important role in developing countries than in developed ones.

Therefore, it is important understanding the process of social media adoption by organizations, social media understood as an innovation that is able to improve the company process and its productivity.

In this sense, various studies have been conducted to investigate the characteristics of innovation adoption by organizations (ROGERS, 1983; MEYER; GÓES, 1988; SANKAR 1991). However, many of these studies have limited themselves to merely transfer the models and methodologies developed to analyze the individual adoption of technological innovation (DAVIS, 1989; MOORE; BENBASAT, 1991; AJZEN, 1991; THOMPSON et al. 1991; DAVIS et al. 1992; TAYLOR; TODD, 1995; COMPEAU; HIGGINS 1995; VENKATESH; DAVIS 2000; VENKATATIONS ESH et al. 2003; VENKATESH et al. 2012). 
Specifically, in searching articles in the Web of Science database it is also remarkable that there are few studies about the social media adoption; and analyzing the most cited articles it can be seen that most of them are focused in individual acceptance of social media (CURTIS et al., 2010; EYRICH, 2008) instead of organizational adoption.

Therefore, there is a gap in terms of developing and testing a model to verify what factors affect the adoption of social media by organizations as a whole, and not just by an individual. Tornatzky and Fleischer (1990) develop one of the most known frameworks to analyze the organizational adoption of technological innovation, the Technology, Organization and Environment (TOE) framework: it identifies three aspects of an enterprise's context that influence the process by which it adopts and implements a technological innovation: technological context, organizational context, and environmental context. In order to enlarge the TOE framework, Frambach and Schillewaert (2002) develop a conceptual multi-level model to verify the organization behavior in terms of innovation adoption, including some aspects like perceived adopter characteristics (innovate predisposition, for example), network participation, among others. However, these authors did not develop any scale in order to effectively measuring their model to identify the main factors that lead companies to adopt a technological innovation.

In this context, the following research objective was "to identify what are the main factors leading companies to adopt social media for business processes".

The main contribution of this paper is related to the fact that, despite several studies about individual adoption of social media, there are few studies about this adoption by the company, taken as a whole, understanding what factors are perceived as crucial in order to adopt this tool in its business processes.

We proposed and tested a theoretical model to answer the research question in order to assess the factors that influence the organizational social media adoption. To answer the research objective, an empirical study was conducted using a survey of 237 companies that incorporated social media into their business processes. We analyzed the model using structural equation modeling and in our analysis, we tried to identify the degree of this adoption, which is understood in terms of the intensity of its use in various company areas or business. 


\section{LITERATURE REVIEW}

Through innovation, companies seek to meet consumer demand for efficiency and responsiveness, increase their productivity, improve product quality and reduce the project cycle to stay ahead of the competition.

The Oslo Manual (OECD 2005, p. 46) defines the term innovation as "the implementation of a new or significantly improved product (good or service), or a process, or a new marketing method, or a new organizational method for business practices, workplace organization or external relations."

One important aspect of innovation is its diffusion: according to Rogers (1983) diffusion is the process by which one innovation is adopted and accepted by members of a certain community.

A widely used model of innovation adoption is the Unified Theory of Acceptance and Use of Technology (UTAUT), developed by Venkatesh et al. (2003), where the authors analyze eight prominent models of innovation adoption and proposed the UTAUT model. However, even this model, takes in account the individual decision in adopting an innovation. In his model, Venkatesh et al. (2003) observed that, despite Information Technology (IT) the acceptance of the research has yielded many competing models, some aspects were still unexplored; so, they have developed a deep research about user acceptance literature, discussing eight models, among them, the social cognitive theory. According to Venkatesh et al. (2003), one of the most powerful theories of human behavior is social cognitive theory.

In this sense, according to Ratten (2014) the process of adoption and implementation of a technology service enables an evaluation of consumer behavioral intentions towards innovation. Still according to Ratten (2014) there are three key stages of the process approach: initiation, process and implementation and she used behavioral intention theories of the technology acceptance model and social cognitive theory to develop and test a number of hypotheses designed to understand the factors influencing intention to use cloud computing services by individuals. Ratten and Ratten (2007) used social cognitive theory in another study about adoption of wireless application protocol (WAP) banking by young people, showing that this theory could be useful to understand the acceptance behavior. In fact, in their study they found that the adoption decision was influenced by outcome values the individuals placed on a new product or service, corroborating other acceptance theories. 
The previous models showed above were related to individual behavior in terms of technology adoption, but they did not consider the organizational behavior. In these terms, the most used framework to analyze technology adoption by organizations was the TOE framework (TORNATZKY; FLEISCHER, 1990). This model is very similar to that of Rogers (1983), but it also includes a new and important component, environment context. The environment context presents both constraints and opportunities for technological innovation. In the TOE model, environment is defined by Industry characteristics and market structure, technology support infrastructure and government regulation; the organization context is defined by formal and informal linking structures, communication processes, its size and slack. The technology is defined by its availability and characteristics. Also in an attempt to broaden the scope from the individual to the organizational environment, Frambach and Schillewaert (2002) propose a multilevel model of innovation adoption that incorporates organizational and individual determinants. This model considers the following constructs determinants of the organization decision to adopt an innovation: the perceived characteristics of innovation, the characteristics of the adopter and environmental influences. The perceived innovation characteristics is influenced by suppliers' marketing effort and the organization's social network and it has influence from the environment.

The characteristics of an innovation that are perceived by potential adopters are at the core of this model. The variables that compose this construct are relative advantage offered by the innovation (that is considered the most important element in the organization's decision to adopt it), compatibility (in accordance with the potential adopter's existing values, previous experiences and needs) and complexity (the extent to which an innovation is perceived as difficult to understand and use). Other variables that compose the perceived innovation characteristics: the possibility of experimentation (on a limited scale), observability (the results of an innovation are visible to others) and uncertainty (a lack of a priori knowledge of the result or effect of innovation adoption).

According to Frambach and Schillewaert (2002), the characteristics of the adopter (an organization), are identified in terms of company size (measured by sales volume or number of employees in the organization) and organizational structure (involving the structure's complexity, degree of formalization and the centralization of decisions). The last variable that identifies adopter characteristics is the organization innovativeness or strategic posture (the degree to which an organization is receptive to new products or ideas). Environmental influences are characterized by the following factors: network externality (interrelated 
organizations in the market environment that have adopted the innovation) and competitive pressures that the market exerts on the company. The suppliers' marketing effort can be observed in the supplier's focus on innovation, its communicate ability and skill and the reduction of risks associated with adopting the innovation promoted by the supplier. The social network is characterized by the organization's interconnectivity with other organizations and the organization's information sharing.

Before the adoption of social media for use in organizational processes can be considered an innovation, the concept should first be defined. According to Boyd and Ellison (2008), social media are web-based services that allow individuals to construct a public or semi-public profile within a limited system, articulate a list of other users with whom they share a connection and view and browse their list of connections and those made by others within the system. Bhagat, Klein and Sharma (2009) go one-step further: to these authors, social media are the online technologies and practices that people use to share opinions, ideas, experiences and perspectives with others.

Acording to Kaplan and Haenlein (2010), social media is a group of internet-based applications that were built on the ideological and technological foundations of Web 2.0, that allow for the creation and exchange of user-generated contents. The individuals make use of user-generated-contents in different ways for different purposes, like to consume usergenerated contents for fulfilling their information, to entertainment, to mood management needs, to interact with the content and other human beings and to produce their own contents on user-generated sites for self-expression and self-actualization (SHAO, 2009).

Recent studies show the importance of using social media in business, for example, to make predictions based on data collected from social media (KALAMPOKIS et al., 2013), to understand offline phenomena by the analysis of online data (JUNGHERR; JÜRGENS, 2013), or to assess the credibility of user-generated contents (CASTILLO et al., 2013). This reveal that the new technologies and new systems that can be accessed through social media change the way companies and corporations use knowledge and innovation abilities to create value, affecting all aspects of management.

\section{RESEARCH MODEL AND HYPOTHESES}

The proposed objective was to analyze the factors that determine organizational social media adoption and identify the degree of this adoption, which is understood in terms of its use in various company areas or business processes. With this in mind, the Organizational Social Media Adoption Model was developed, based on Frambach and Schillewaert (2002), 
Tornatzky and Fleischer (1990) (the TOE model), Venkatesh et al (2003) and Ratten and Ratten (2007) (Figure 1).

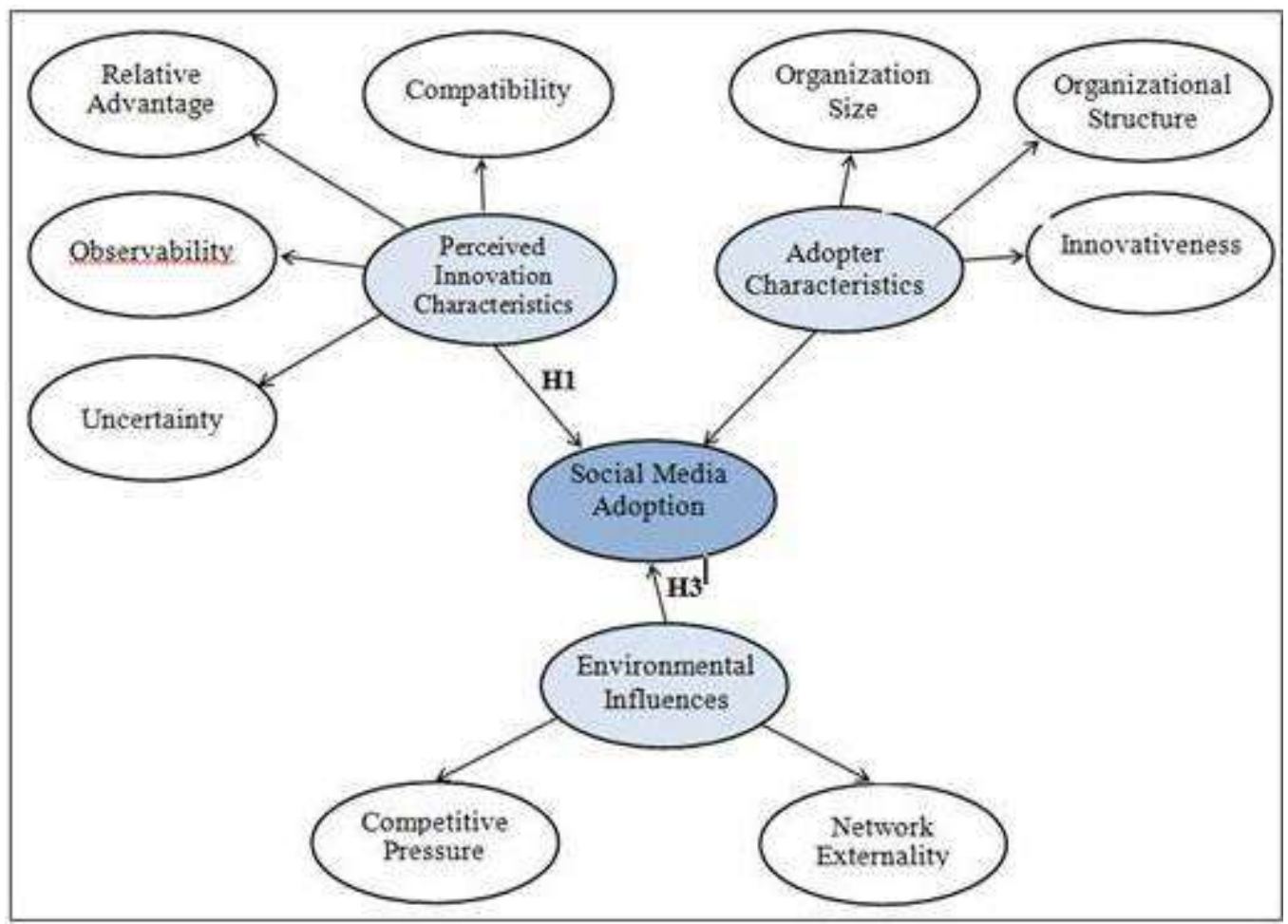

Figure 1 - Research Model with Hypotheses

In the TOE model (TORNATZKY; FLEISCHER, 1990) the authors propose that the technology, the environment and the organization contexts influence the innovation adoption, but they don't consider the adopter's characteristics, what is taking in account in Frambach and Schillewaert (2002) model. According to Ratten and Ratten (2007), their proposed model "is consistent with the foundations of social cognitive theory in that individuals acquire new ideas and knowledge of new practices from their environment, through the media and by observing other people", what can be seen in our model in the variable "Environmental Influences".

The analysis of adoption must be adapted to the relevant innovation or technology (FRAMBACH; SCHILLEWAERT, 2002), thus, the variables in the original models used were adjusted to address the degree of social media use and their adaptation to this specific reality. Thus, the constructs indicators from "perceived innovation characteristics", "adopter characteristics" and "environmental influences" suffered some adjustments that will be explained in the next sections. According to the Model for Innovation Adoption (FRAMBACH; SCHILLEWAERT, 2002), these constructs have a direct relationship with the decision to adopt an innovation. In our model, let us stick to the organizational adoption and 
will not be concerned about the next step, the acceptance of the individual within the organization.

\subsection{PERCEIVED INNOVATION CHARACTERISTICS}

The construct "perceived innovation characteristics" in the multilevel model for Innovation Adoption (FRAMBACH; SCHILLEWAERT, 2002), identifies the benefits and difficulties perceived by the innovation adopter. In the original model, the variables "relative advantage", "compatibility", "observability", "uncertainty", "trialability" and "complexity" define this construct (obs: all these constructs were defined in item 2-background). Social media are widespread and freely available, can be encountered at any time and have an interface that is easy for users to manage (SAFKO, 2010). Thus, the constructs "complexity" (the extent to which an innovation is perceived as difficult to understand and use) and "trialability" (the extent to which an innovation can be tested on a limited scale) were considered to have no influence and were disregarded in this work. This study considered the constructs "relative advantage", "compatibility", "observability" and "uncertainty" defined below in section 2, to influence the variable "perceived innovation characteristics" related to the use of social media.

According to Frambach and Schillewaert (2002), corroborating the results of work performed by Rogers (1983) and Moore and Benbasat (1991), the perception that an organization's members have regarding an innovation affects their propensity to adopt it. Therefore, we propose the following:

Hypothesis 1 - The perceived innovation characteristics positively influence organizational social media adoption.

The variable "perceived innovation characteristics" is formed by the following constructs: "Relative advantages", "Compatibility", "Observability" and "Uncertainty". "Relative advantages" refer to the perceived benefits that virtual social network adoption can have for the organization. A better understanding of the managerial advantage of an innovation increases the likelihood of allocating the managerial, financial and technological resources necessary to use the innovation (ROGERS, 1983). Several authors (TAN; THOEN 2001; TEO; POK 2003; PAPIERS; CLEMENT, 2008) find that relative advantage is a major factor in the adoption of innovations based on Information Technology (IT).

According to Venkatesh et al. (2003), within Information System, "Moore and Benbasat (1991) adapted the characteristics of innovation present in Rogers and refined a set of 
constructs that could be used to study individual technology acceptance". Yet in this regard, Moore and Benbasat (1991) state that although there were many research in terms of identifying the elements that conduct to the innovation adoption in Information Technology (IT), the scales did not have the validity and reliability necessary, so they decided to measure the potential adopters' perception of technology rather than the perception of innovation itself. One of the constructs that form the variable "perceived innovation characteristics" is the construct "Compatibility", that can be expressed "as the degree to which an innovation is perceived as being consistent with the existing values, past experiences and needs of potential adopters" (MOORE; BENBASAT, 1991, p. 195). An idea that is incompatible with the values and norms of a social system will not be adopted as rapidly as a compatible innovation (Rogers 1983). According to Ilie et al. (2005), compatibility between the innovation to be adopted and the business environment allows the innovation to be interpreted as familiar. As our innovation being studied is the social media, we can say that if the potential adopter sees the social media as something compatible to the other IT tools, then this perceived characteristic will lead to the adoption of social media.

"Observability" allows the results of an innovation to be visible to others (Moore and Benbasat, 1991). This visibility stimulates peer discussion of a new idea, for example, with an adopter's partners (ROGERS, 1983). According to Moore and Benbasat (1991) observability will reflect the ability to measure, observe and communicate the results of using the innovation. In our case, the social media observability is related to the results that can be observed in using social media, for example, if a company has a Facebook account, this fact can generate more interaction with their consumers. So, this perceived characteristic can lead to the social media adoption. Thus, the observability of results encourages further adoption of innovations such as social media.

According to Frambach and Schillewaert (2002), "uncertainties" can be classified into three categories:

a) Technical, expressing the difficulty experienced by the potential adopter in determining the reliability and the functionality of an innovation;

b) Financial, expressing the difficulty of determining whether the adoption will be financially attractive, and 
c) Social, understood as the acceptability of conflicts related to the potential adoption of an innovation in the adopter's organizational environment. These uncertainties diminish the propensity to adopt an innovation, such as social media.

\subsection{ADOPTER CHARACTERISTICS}

The variable "adopter characteristics" is composed of the constructs "organization size", "organizational structure" and "organizational disposition innovativeness". According to Rogers (1983), Tornatzky and Fleischer (1990) and Frambach and Schillewaert (2002), the characteristics of the adopter are paramount to innovation adoption, which is why one may assume the following hypothesis:

Hypothesis 2 - The adopter characteristics positively influence the organizational social media adoption.

Regarding the construct "organizational size", according to Rogers (1983) and Damanpour (1996), large companies have a greater propensity to adopt innovations than smaller companies because they tend to enjoy a greater amount of resources. "The size (of the company) is likely a surrogate measure of the various dimensions that lead to innovation adoption: total resources, slack resources and worker technique and expertise (...)" (ROGERS, 1983, p. 379). Studies conducted by Zhu, Kraemer and Xu (2006) also observed this relationship. The adoption of virtual social networks in company business processes requires the commitment of technical and managerial resources. Therefore, larger organizations are more likely to adopt social media because of their resource advantages.

The construct "Organizational structure" can be defined as a set of formal tasks assigned to individuals and departments; formal command relationships, which include lines of authority, decision responsibility, number of hierarchical levels and extent of managerial control; and systems design, to ensure the effective coordination of employees across departments (DAFT, 2005). In an organization with a centralized organizational structure, employees may be unable to sufficiently absorb innovations and lack the ability to react quickly to change paradigms (CALANTONE et al., 2002; HULT et al., 2002). According to Chen and Chang (2012), a centralized organizational structure, complexity and an excess of rules and formalism affect an organization's capacity for innovation adoption, as well as hinder the absorption of knowledge produced by innovation adoption. Thus, an organization that has a high degree of centralization in decision-making and formalism and is organizationally complex can complicate the adoption of social media in business processes. 
"Organizational disposition innovativeness" refers to the company's willingness to support creativity and experimentation in new product development, technology adoption and internal processes and procedures, reflecting a readiness to depart from the status quo and adopt new ideas (LUMPKIN; DESS, 1996). According to Carayannis and Provance (2008), innovativeness involves a company's ability to capitalize on its position based on the cultural acceptance of innovation, reflected in the company's processes, routines and capabilities. In the context of corporate social media adoption, innovativeness can be measured by the necessity of innovation to the company's survival and by active employee participation in innovation adoption.

\subsection{ENVIRONMENTAL INFLUENCES}

Frambach and Schillewaert (2002) states that the environment can affect the adoption in two ways:

1- Deriving from benefits from business partners, that have already adopted the innovation (in a form of network externality); 2- Competitive pressure may promote adoption.

According to Rogers (1983), Tornatzky and Fleischer (1990) and Ratten and Ratten (2007), the external environment influences innovation adoption, indicating why we may assume the following hypothesis:

Hypothesis 3 - Environmental influences exert a positive influence on the organizational social media adoption.

Therefore, in our model, the variable "environmental influences" comprises the variables "competitive pressures" and "network externalities".

"Competitive pressures" can be defined as "the degree to which a company is affected by market competition" (ZHU et al., 2006, p. 1564). Competitive pressures' effect on the use of virtual social networks can vary depending on when this adoption progresses to a more comprehensive stage. Competition can influence companies to adopt innovations to maintain a competitive advantage. Porter (2001) argues that by integrating business processes with online activities, companies can change the rules of competition, affecting the industry's structure and leveraging new ways to surpass their rivals. Based on tools available on the Internet, the use of virtual social networks can aid companies in improving market responsiveness and information transparency (ZHU, 2004), increasing operational efficiency (ZHU et al., 2006) and retaining customers (TAPSCOTT; WILLIAMS, 2007): key initiatives that allow a company to maintain its competitive advantage (PORTER, 2001). 
"Network externalities" occurs when the demand exerted by a person or organization can be influenced by other consumers who have already purchased the product (PINDYCK; RUBINFELD, 2005). Transferring the concept of network externality to innovation adoption, the value of an innovation and its probability of adoption are intrinsically determined by whether other users, who are either part of a company's network of relationships or belong to the same value chain in which the company operates, adopt it.

\section{METHOD AND EMPIRICAL STUDY}

According to the classifications of research presented by Gil (2002) and Malhotra (2004), this research is classified as descriptive and has a causal character because it aims to identify the factors determining corporate social media adoption. In the present work, "degree of intensity" was used to measure the extent to which social media has been adopted within a company. This degree ranged from use in only one of the company's areas or business processes to use in several areas or business processes. Use in only one area corresponds to lower adoption intensity, and the more areas or processes there are using these media, the greater this innovation's degree of adoption.

With regard to objective, this research has an explicative or explanatory character, seeking to explain relationships between variables (GIL, 2002). From a temporal point of view, the study was characterized as cross-sectional (MALHOTRA, 2004), using the survey method by applying an online questionnaire using "SurveyMonkey", a tool for developing and distributing questionnaires.

\subsection{DEVELOPING THE RESEARCH INSTRUMENT}

To define the scales used in the questionnaire's construction, this research relied on several studies found in the academic literature and used in the proposed theoretical framework in the background section of this paper. The choice was made to measure the model's constructs using ordinal indicators, consisting of a seven-point Likert scale ranging from "strongly disagree" (value $=1$ ) to "strongly agree" (value $=7$ ). In addition to the indicator variables of the constructs to be measured, variables related to the respondents' identity were included in the data collection instrument. These variables included:

(a) economic sector, as identified in accordance with the National Classification of Economic Activities (CNAE in Portuguese) (b) branch of activity, which is a breakdown of the company's economic sector, (c) the origin of the company's capital or controlling interest and (d) the position equivalent to the position held by the questionnaire's respondent. This method resulted in a questionnaire composed of 17 questions and 52 indicators related to the 
variables in the theoretical model. Table 1 list the measurement of the indicators used in the questionnaire, showing the theoretical source of these indicators.

\begin{tabular}{|c|c|c|c|c|}
\hline Variable & Construct & & Indicators & Theoretical Source \\
\hline \multirow{18}{*}{$\begin{array}{l}\text { Perceived } \\
\text { Innovation } \\
\text { Characteristics }\end{array}$} & \multirow{9}{*}{$\begin{array}{l}\text { Relative } \\
\text { Advantage }\end{array}$} & VR1 & $\begin{array}{l}\text { The use of social media improves } \\
\text { exposure to the company's brand(s) } \\
\text { or product(s) }\end{array}$ & \multirow{9}{*}{$\begin{array}{c}\text { Rogers (1983); Frambach e } \\
\text { Schillewaert (2002); Tan e } \\
\text { Thoen (2001); Teo e Pok } \\
\text { (2003); Papiers e Clement } \\
\text { (2008) }\end{array}$} \\
\hline & & VR2 & $\begin{array}{l}\text { The incorporation of social media } \\
\text { into the company's business } \\
\text { processes differentiates the company } \\
\text { from its competitors }\end{array}$ & \\
\hline & & VR3 & $\begin{array}{l}\text { The use of social media produces an } \\
\text { increase in company revenues }\end{array}$ & \\
\hline & & VR4 & $\begin{array}{l}\text { The use of social media allows the } \\
\text { company to operate in unexplored } \\
\text { market niches }\end{array}$ & \\
\hline & & VR5 & $\begin{array}{l}\text { The use of social media improves } \\
\text { customer relationships }\end{array}$ & \\
\hline & & VR6 & $\begin{array}{l}\text { The use of social media improves } \\
\text { supplier relationships }\end{array}$ & \\
\hline & & VR7 & $\begin{array}{l}\text { The use of social media improves } \\
\text { employee relationships }\end{array}$ & \\
\hline & & VR8 & $\begin{array}{l}\text { The use of social media improves the } \\
\text { process of hiring new employees }\end{array}$ & \\
\hline & & VR9 & $\begin{array}{l}\text { The use of social media increases the } \\
\text { amount of information provided to } \\
\text { customers about the products } \\
\text { marketed }\end{array}$ & \\
\hline & \multirow{5}{*}{ Compatibility } & $\mathrm{CP} 1$ & $\begin{array}{l}\text { The technology used by social media } \\
\text { is compatible with the company's } \\
\text { technological environment }\end{array}$ & \multirow{5}{*}{$\begin{array}{c}\text { Rogers (1983); Frambach e } \\
\text { Schillewaert (2002); Ilie et al. } \\
\text { (2005) }\end{array}$} \\
\hline & & $\mathrm{CP} 2$ & $\begin{array}{l}\text { The use of social media is compatible } \\
\text { with the need for speed in the } \\
\text { execution of the company's business } \\
\text { process }\end{array}$ & \\
\hline & & $\mathrm{CP} 3$ & $\begin{array}{l}\text { The use of social media is compatible } \\
\text { with the way employees } \\
\text { communicate with people outside the } \\
\text { company }\end{array}$ & \\
\hline & & $\mathrm{CP} 4$ & $\begin{array}{l}\text { The use of social media in company } \\
\text { activities is consistent with the way } \\
\text { employees communicate with } \\
\text { coworkers }\end{array}$ & \\
\hline & & CP5 & $\begin{array}{l}\text { The use of social media in company } \\
\text { activities is compatible with the } \\
\text { company's need for information } \\
\text { outside of the work environment }\end{array}$ & \\
\hline & \multirow{4}{*}{ Observability } & PB1 & $\begin{array}{l}\text { The advantages obtained with the use } \\
\text { of social media are widely } \\
\text { commented on by the company's } \\
\text { customers }\end{array}$ & \multirow{3}{*}{$\begin{array}{c}\text { Rogers (1983); Frambach e } \\
\text { Schillewaert (2002); Moore and } \\
\text { Benbasat (1991) }\end{array}$} \\
\hline & & PB2 & $\begin{array}{l}\text { The company began to use social } \\
\text { media in its business processes } \\
\text { because of the results their } \\
\text { competitors obtained with this tool }\end{array}$ & \\
\hline & & PB3 & $\begin{array}{l}\text { The results of corporate social media } \\
\text { adoption are perceived by customers }\end{array}$ & \\
\hline & & PB4 & $\begin{array}{l}\text { There is confidence in the use of } \\
\text { social media in the company's } \\
\text { business processes because of results } \\
\text { achieved in company tests using this } \\
\text { tool }\end{array}$ & $\begin{array}{c}\text { Rogers (1983); Frambach e } \\
\text { Schillewaert (2002); Moore and } \\
\text { Benbasat (1991) }\end{array}$ \\
\hline
\end{tabular}




\begin{tabular}{|c|c|c|c|c|}
\hline Variable & Construct & & Indicators & Theoretical Source \\
\hline & & PB5 & $\begin{array}{l}\text { Media coverage on the company's } \\
\text { use of social media promotes } \\
\text { confidence in the use of this tool in } \\
\text { company activities }\end{array}$ & \\
\hline & & PB6 & $\begin{array}{l}\text { The acceptance of customers, } \\
\text { suppliers or employees is visible } \\
\text { through the company's use of social } \\
\text { media }\end{array}$ & \\
\hline & \multirow{7}{*}{ Uncertainty } & IN1 & $\begin{array}{l}\text { The costs of adopting social media in } \\
\text { company activities are difficult to } \\
\text { measure }\end{array}$ & \multirow{7}{*}{ Frambach e Schillewaert (2002) } \\
\hline & & IN2 & $\begin{array}{l}\text { The results obtained from the } \\
\text { incorporation of social media into the } \\
\text { company's activities are little known }\end{array}$ & \\
\hline & & IN3 & $\begin{array}{l}\text { Potential security and privacy risks } \\
\text { hinder the use of social media in } \\
\text { company activities }\end{array}$ & \\
\hline & & IN4 & $\begin{array}{l}\text { There are important legal issues } \\
\text { regarding the use of social media that } \\
\text { remain unresolved }\end{array}$ & \\
\hline & & IN5 & $\begin{array}{l}\text { There is no guarantee that currently } \\
\text { available social media will be } \\
\text { available in the future }\end{array}$ & \\
\hline & & IN6 & $\begin{array}{l}\text { The current compatibility with the } \\
\text { technological environment necessary } \\
\text { for social media adoption may not } \\
\text { exist in the future }\end{array}$ & \\
\hline & & IN7 & $\begin{array}{l}\text { The use of social media in the } \\
\text { company's business processes can } \\
\text { generate conflicts because of current } \\
\text { organizational culture }\end{array}$ & \\
\hline \multirow{15}{*}{$\begin{array}{l}\text { Adopter } \\
\text { Characteristics }\end{array}$} & \multirow{7}{*}{ Organization Size } & TO1 & Less than or equal to $\mathrm{R} \$ 2.4$ million & \multirow{7}{*}{$\begin{array}{l}\text { Rogers (1983); Damanpour } \\
\text { (1996); Frambach e } \\
\text { Schillewaert (2002); Zhu, } \\
\text { Kraemer e Xu (2006) }\end{array}$} \\
\hline & & TO2 & $\begin{array}{l}\text { Greater than } \mathrm{R} \$ 2.4 \text { million and less } \\
\text { than or equal to } \mathrm{R} \$ 9 \text { million }\end{array}$ & \\
\hline & & TO3 & $\begin{array}{l}\text { Greater than } \mathrm{R} \$ 9 \text { million and less } \\
\text { than or equal to } \mathrm{R} \$ 16 \text { million }\end{array}$ & \\
\hline & & TO4 & $\begin{array}{l}\text { Greater than } R \$ 16 \text { million and less } \\
\text { than or equal to } R \$ 150 \text { million }\end{array}$ & \\
\hline & & TO5 & $\begin{array}{l}\text { Greater than } R \$ 150 \text { million and less } \\
\text { than or equal to } R \$ 300 \text { million }\end{array}$ & \\
\hline & & TO6 & $\begin{array}{l}\text { Greater than } \mathrm{R} \$ 300 \text { million and less } \\
\text { than or equal to } \mathrm{R} \$ 1 \text { billion }\end{array}$ & \\
\hline & & TO7 & Greater than $\mathrm{R} \$ 1$ billion & \\
\hline & & EE1 & $\begin{array}{l}\text { The decision to adopt innovations is } \\
\text { always centralized at the company's } \\
\text { highest decision level }\end{array}$ & \\
\hline & & EE2 & $\begin{array}{llll}\begin{array}{l}\text { The company has } \\
\text { organizational structure }\end{array} & \text { rigid } \\
\end{array}$ & \\
\hline & & EE3 & $\begin{array}{l}\text { The decision on how social media are } \\
\text { used in the company is centralized at } \\
\text { the company's highest decision level }\end{array}$ & \\
\hline & Organizational & EE4 & $\begin{array}{l}\text { The company has several units with } \\
\text { different purposes (product, different } \\
\text { services, etc.) }\end{array}$ & $\begin{array}{c}\text { Calantone, Cavusgil e Zhao } \\
\text { (2002); Frambach e } \\
\text { Schillewaert (2002); Hult, }\end{array}$ \\
\hline & Structure & EE5 & $\begin{array}{l}\text { The company has several } \\
\text { organizational units, manufacturing } \\
\text { plants or geographically distant } \\
\text { offices }\end{array}$ & $\begin{array}{l}\text { Ferrell e Hurley (2002); Daft } \\
\text { (2005); Chen e Chang (2012) }\end{array}$ \\
\hline & & EE6 & $\begin{array}{l}\text { The company has more than three } \\
\text { managerial levels }\end{array}$ & \\
\hline & & EE7 & $\begin{array}{l}\text { The company has formally } \\
\text { established policies and procedures }\end{array}$ & \\
\hline & & EE8 & $\begin{array}{l}\text { The company's rules and procedures } \\
\text { are tightly controlled }\end{array}$ & \\
\hline
\end{tabular}




\begin{tabular}{|c|c|c|c|c|}
\hline \multirow[t]{7}{*}{ Variable } & \multirow[t]{2}{*}{ Construct } & \multicolumn{2}{|r|}{ Indicators } & \multirow[t]{2}{*}{ Theoretical Source } \\
\hline & & EE9 & $\begin{array}{l}\text { The company encourages formal } \\
\text { relationships between employees at } \\
\text { different hierarchical levels }\end{array}$ & \\
\hline & \multirow{5}{*}{$\begin{array}{l}\text { Organizational } \\
\text { Disposition } \\
\text { Innovativeness }\end{array}$} & PI1 & $\begin{array}{l}\text { Innovation adoption is necessary for } \\
\text { the company's survival }\end{array}$ & \multirow{5}{*}{$\begin{array}{c}\text { Lumpkin e Dess (1996); } \\
\text { Frambach e Schillewaert } \\
\text { (2002); Carayannis e Provance } \\
\text { (2008) }\end{array}$} \\
\hline & & PI2 & $\begin{array}{l}\text { Suggestions made by employees or } \\
\text { clients are readily accepted by the } \\
\text { management }\end{array}$ & \\
\hline & & PI3 & $\begin{array}{l}\text { The company invests in employee } \\
\text { training to produce creative solutions } \\
\text { for business processes }\end{array}$ & \\
\hline & & PI4 & $\begin{array}{l}\text { The company often seeks innovative } \\
\text { ideas to apply to its activities }\end{array}$ & \\
\hline & & PI5 & $\begin{array}{l}\text { The company's culture constantly } \\
\text { seeks to innovate }\end{array}$ & \\
\hline \multirow{11}{*}{$\begin{array}{l}\text { Environmental } \\
\text { Influences }\end{array}$} & \multirow{7}{*}{$\begin{array}{l}\text { Competitive } \\
\text { Pressures }\end{array}$} & $\mathrm{PC} 1$ & $\begin{array}{l}\text { The products marketed by the } \\
\text { company are similar to others on the } \\
\text { market }\end{array}$ & \multirow{7}{*}{$\begin{array}{c}\text { Porter (2001); Frambach e } \\
\text { Schillewaert (2002); Zhu } \\
\text { (2004); Zhu, Kraemer e Xu } \\
\text { (2006); Tapscott e Willians } \\
\text { (2007); }\end{array}$} \\
\hline & & $\mathrm{PC} 2$ & $\begin{array}{l}\text { There are many competitors in the } \\
\text { industry in which the company } \\
\text { operates }\end{array}$ & \\
\hline & & PC3 & $\begin{array}{l}\text { There is great competition to sell } \\
\text { products at a lower price than } \\
\text { competitors in the market in which } \\
\text { the company operates }\end{array}$ & \\
\hline & & $\mathrm{PC} 4$ & $\begin{array}{l}\text { There is great competition to have a } \\
\text { better quality product than } \\
\text { competitors in the market in which } \\
\text { the company operates }\end{array}$ & \\
\hline & & PC5 & $\begin{array}{l}\text { There is great competition to have a } \\
\text { larger variety of products than } \\
\text { competitors in the market in which } \\
\text { the company operates }\end{array}$ & \\
\hline & & PC6 & $\begin{array}{l}\text { There is great competition to offer } \\
\text { better after-sales service than } \\
\text { competitors in the market in which } \\
\text { the company operates }\end{array}$ & \\
\hline & & PC7 & $\begin{array}{l}\text { The tools that the company makes } \\
\text { available on the Internet are a } \\
\text { differentiating factor between } \\
\text { companies in the company's segment }\end{array}$ & \\
\hline & \multirow{4}{*}{$\begin{array}{l}\text { Network } \\
\text { Externalities }\end{array}$} & ER1 & $\begin{array}{l}\text { The company began to use social } \\
\text { media that its competitors were using }\end{array}$ & \multirow{4}{*}{$\begin{array}{c}\text { Frambach e Schillewaert } \\
\text { (2002); Pindyck e Rubinfeld } \\
\text { (2005); Ratten and Ratten } \\
\text { (2007) }\end{array}$} \\
\hline & & ER2 & $\begin{array}{l}\text { The company began to use social } \\
\text { media that its customers were using }\end{array}$ & \\
\hline & & ER3 & $\begin{array}{l}\text { The company began to use social } \\
\text { media that its suppliers were using }\end{array}$ & \\
\hline & & ER4 & $\begin{array}{l}\text { The company began to use social } \\
\text { media that its employees were using }\end{array}$ & \\
\hline
\end{tabular}

Table 1 - Measurement of the independent variables

To keep measuring compatibility with the 7-point scale used in other indicators, the variable "organization size" was measured as described in table 1.

The dependent variable "Social Media Adoption" was considered a proxy variable and it was measured according to the adoption degree of intensity. This degree ranged from use in only one of the company's areas or business processes to use in several areas or business processes. The use only in an area corresponding to the lower intensity of adoption and as 
more areas or processes use these social media, higher the level of adoption. Table 2 shows the indicators of this variable.

\begin{tabular}{|c|c|c|c|}
\hline Variable & & Indicators & Variable Type \\
\hline \multirow{10}{*}{$\begin{array}{l}\text { Social Media } \\
\text { Adoption } \\
\text { (dependent } \\
\text { variable) }\end{array}$} & MS1 & $\begin{array}{l}\text { Social media are used extensively in the } \\
\text { company's marketing department }\end{array}$ & \multirow{10}{*}{ Proxy Variable } \\
\hline & MS2 & $\begin{array}{l}\text { Social media are used extensively in the } \\
\text { company's human resources department }\end{array}$ & \\
\hline & MS3 & $\begin{array}{l}\text { Social media are used extensively in the } \\
\text { company's sales department }\end{array}$ & \\
\hline & MS4 & $\begin{array}{l}\text { Social media are used extensively in the } \\
\text { company's logistics department }\end{array}$ & \\
\hline & MS5 & $\begin{array}{l}\text { Social media are used extensively in the } \\
\text { company's research and development (R\&D) } \\
\text { department }\end{array}$ & \\
\hline & MS6 & $\begin{array}{l}\text { Social media are used extensively in the } \\
\text { company's financial department }\end{array}$ & \\
\hline & MS7 & $\begin{array}{l}\text { Social media are used extensively in the } \\
\text { company's production department }\end{array}$ & \\
\hline & MS8 & $\begin{array}{l}\text { Social media are used extensively in the } \\
\text { company's communications department }\end{array}$ & \\
\hline & MS9 & $\begin{array}{l}\text { Social media are used extensively for } \\
\text { product development }\end{array}$ & \\
\hline & MS10 & $\begin{array}{l}\text { Social media are used extensively in another } \\
\text { of the company's departments. Department: }\end{array}$ & \\
\hline
\end{tabular}

Table 2 - Measurement of the dependent variables

It is important to note that the development of this scale is one of this work contribution.

The questionnaire (scales) was validated through an evaluation conducted by three academic experts in strategy and innovation, besides the face-to-face application of the questionnaire in three companies incorporating social media into their business processes. In addition, a pilot test conducted on 10 companies permitted to answer the questionnaire without researcher monitoring to ensure the adequacy and comprehension of the concepts employed.

\subsection{DATA COLLECTION}

For the sake of convenience, non-probabilistic criteria were used to obtain the sample (COOPER; SCHINDLER, 2003). The research universe was composed of companies established in Brazil that have incorporated social media into their business processes. According to the Brazilian Institute of Geography and Statistics (IBGE, 2010), there are approximately five million companies in Brazil, and according to Deloitte (2010), 70\% of the companies established in Brazil use some form of social media.

Schumacker and Lomax (2004) note that 100 observations is the minimum sample size necessary to perform an analysis with structural equation models. According to Chin (1998), using the partial least squares analysis method, the sample should exhibit at least 10 elements for each relationship or path of the structural equation model studied. According to Hair 
Junior et al. (2009) and Schumacker and Lomax (2004), there is no consensus on how to calculate optimal sample size, and a general rule would be between 15 and 20 observations per variable, which results in a sample of between 195 and 260 companies to be researched.

Access to the companies was obtained in three stages:

1. During the data collection preparation stage companies incorporating social media into their business processes were identified. For that, we use the "Biggest and Best" ranking provided by Exame magazine (2012) (large or medium), the "Fastest growing SMEs in Brazil" study, prepared by Deloitte (2012) (small or medium), and a database of 1,258 micro and small companies, provided through a partnership with the São Paulo Commercial Association. Company size was identified using the classification based on annual revenues, established by the Brazilian Development Bank (BNDES, 2011). To identify companies incorporating social media into their business processes, research was conducted on the social media sites Facebook, LinkedIn, Orkut and Twitter to verify whether the companies listed during the previous stages were using these media.

2. Using the social media sites Facebook and LinkedIn as communication channels, during the second stage, a total of 473 messages were sent to people who were responsible for the adoption process or the use of social media in the selected companies and had some contact with the researcher. Ninety-four responses provided without researcher support were collected during a two-week period, corresponding to a share of $20 \%$ of the questionnaires sent.

3. In the third stage, telephone contact was made with 105 respondents who had received the questionnaire through social networks but had not completed it to collect data with researcher support. Contact was also made with 243 companies that had not received the questionnaire via Internet, and these questionnaires were also monitored for completion.

As a result, the questionnaire was sent to 821 companies and 271 questionnaires were obtained, resulting in a response rate of $33 \%$. After eliminating incomplete questionnaires, 237 totally completed questionnaires were left, constituting the final sample.

It is important to highlight that we addressed only people responsible for the social media adoption process or for the use of social media in the organization. 
A total of $27 \%$ of the companies surveyed are from the service sector, $24 \%$ are from the commercial sector, $14 \%$ are from the industrial sector, $12 \%$ are from the information and communication sector, $5 \%$ are from the financial sector, and $18 \%$ are from other economic sectors. Microenterprises accounted for $24 \%$ of the companies surveyed, $21 \%$ are small companies, $18 \%$ are medium companies, and $37 \%$ are large companies. Foreign-invested companies compose $24 \%$ of the sample, mainly forming the group of large companies.

The relationships between the latent constructs proposed in this paper were tested using statistical procedures known as Structural Equation Modeling (SEM). First, multicollinearity was assessed by examining the tolerance and the variance inflation factor (VIF); the tolerance for VIF values was less than 10, and tolerance for tolerance values was greater than 0.1 (Hair et al. 2009). Then, the Kolmogorov-Smirnov normality test was performed, showing that all tested variables were significant $(\mathrm{p}<0.05)$, which indicates that the model's entire distribution was not normal. This result indicates that partial least squares (PLS) analysis is the best method of evaluating the proposed model (CHIN, 1998).

\section{PRESENTATION OF RESULTS}

Data were analyzed by means of structural equation modeling, a multivariate statistical technique applied using the Smart PLS 2.0 software. The results shown in Table 3 were obtained after four statistical interactions. We observe that given that organization size is measured using a single indicator, it does not make sense to report it in table 3.

Table 3 - Analysis of Convergent Validity

\begin{tabular}{l|c|c|c|c|c}
\hline \multicolumn{1}{c|}{ Construct } & AVE & $\sqrt{\text { AVE }}$ & $\begin{array}{c}\text { Reliability } \\
\text { Composition }\end{array}$ & Commonality & Redundancy \\
\hline Relative Advantage & 0.54 & 0.73 & 0.85 & 0.54 & 0.00 \\
Compatibility & 0.77 & 0.88 & 0.94 & 0.77 & 0.00 \\
Observability & 0.81 & 0.90 & 0.96 & 0.81 & 0.00 \\
Uncertainty & 0.62 & 0.79 & 0.77 & 0.62 & 0.00 \\
Organizational Structure & 0.64 & 0.80 & 0.91 & 0.64 & 0.00 \\
Organiz. Disposition Innovativeness & 0.66 & 0.81 & 0.90 & 0.66 & 0.00 \\
Competitive Pressure & 0.65 & 0.81 & 0.92 & 0.65 & 0.00 \\
Network Externality & 0.81 & 0.90 & 0.90 & 0.81 & 0.00 \\
Social Media Adoption & 0.65 & 0.81 & 0.94 & 0.65 & 0.22 \\
\hline
\end{tabular}

The indices found indicated satisfactory results for AVE (above 0.50), and redundancy (maximum 0.50), according to the indices recommended by Chin (1998). Based on the results found, the model was considered to have convergent validity.

To discriminant performance verification, were considered the notes necessary of distinction among latent variables to the discriminant validation of the model, as shown in Table 4. 
Table 4 - Analysis of Discriminant Validity

\begin{tabular}{|c|c|c|c|c|c|c|c|c|c|c|c|}
\hline \multicolumn{2}{|l|}{ Construct } & VR & $\mathrm{CP}$ & PB & IN & TM & EE & PI & $\mathrm{PC}$ & ER & MS \\
\hline \multicolumn{2}{|l|}{ Relative Advantage } & 0.734 & & & & & & & & & \\
\hline \multicolumn{2}{|l|}{ Compatibility } & 0.502 & 0.876 & & & & & & & & \\
\hline \multicolumn{2}{|l|}{ Observability } & 0.718 & 0.397 & 0.901 & & & & & & & \\
\hline \multicolumn{2}{|l|}{ Uncertainty } & 0.148 & 0.265 & 0.315 & 0.788 & & & & & & \\
\hline \multicolumn{2}{|l|}{ Organization Size } & 0.407 & 0.193 & 0.419 & 0.140 & 1.000 & & & & & \\
\hline \multicolumn{2}{|l|}{ Organizational Structure } & 0.558 & 0.160 & 0.643 & 0.166 & 0.699 & 0.799 & & & & \\
\hline \multicolumn{2}{|c|}{ Organiz. Disp. Innovativeness } & 0.617 & 0.631 & 0.718 & 0.272 & 0.398 & 0.550 & 0.810 & & & \\
\hline \multicolumn{2}{|c|}{ Competitive Pressure } & 0.396 & 0.662 & 0.240 & 0.243 & 0.092 & 0.051 & 0.575 & 0.808 & & \\
\hline \multicolumn{2}{|l|}{ Network Externality } & 0.006 & 0.581 & -0.078 & 0.228 & -0.203 & -0.375 & 0.231 & 0.620 & 0.902 & \\
\hline \multicolumn{2}{|l|}{ Social Media Adoption } & 0.676 & 0.378 & 0.673 & 0.197 & 0.387 & 0.575 & 0.655 & 0.305 & 0.004 & 0.804 \\
\hline \multicolumn{12}{|l|}{ Note: } \\
\hline I & \multicolumn{4}{|c|}{ Perceived Innovation Characteristics } & $\mathrm{E}$ & \multicolumn{6}{|c|}{ Organizational Structure } \\
\hline $\mathrm{R}$ & \multicolumn{4}{|c|}{ Relative Advantage } & I & & \multicolumn{3}{|c|}{ Innovativeness } & & \\
\hline $\mathrm{P}$ & \multicolumn{4}{|c|}{ Compatibility } & A & & \multicolumn{5}{|c|}{ Environmental Influences } \\
\hline B & \multicolumn{4}{|c|}{ Observability } & $\mathrm{C}$ & & \multicolumn{5}{|c|}{ Competitive Pressure } \\
\hline $\mathrm{N}$ & \multicolumn{4}{|c|}{ Uncertainty } & $\mathrm{R}$ & & \multicolumn{5}{|c|}{ Network Externality } \\
\hline A & \multicolumn{4}{|c|}{ Adopter Characteristic } & $\mathrm{S}$ & & \multicolumn{5}{|c|}{ Degree of Social Media Adoption } \\
\hline M & \multicolumn{4}{|l|}{ Size } & & const & \multicolumn{5}{|c|}{ Square root of AVE of the } \\
\hline
\end{tabular}

Once the indices were examined, it was observed no occurrence of correlation values between variables that are higher than the value of the "square root of AVE" of the constructs. Given this result, the model was considered to have discriminant validity.

When structural equation modeling techniques were used, the scales built were considered valid for the proposed model after the variables were cleaned and adjustments were made to the model by determining convergent validity and discriminant validity (Chin 1998). Thus, the next step was to analyze the load of the paths proposed in the model using the structural model shown in Figure 2. 


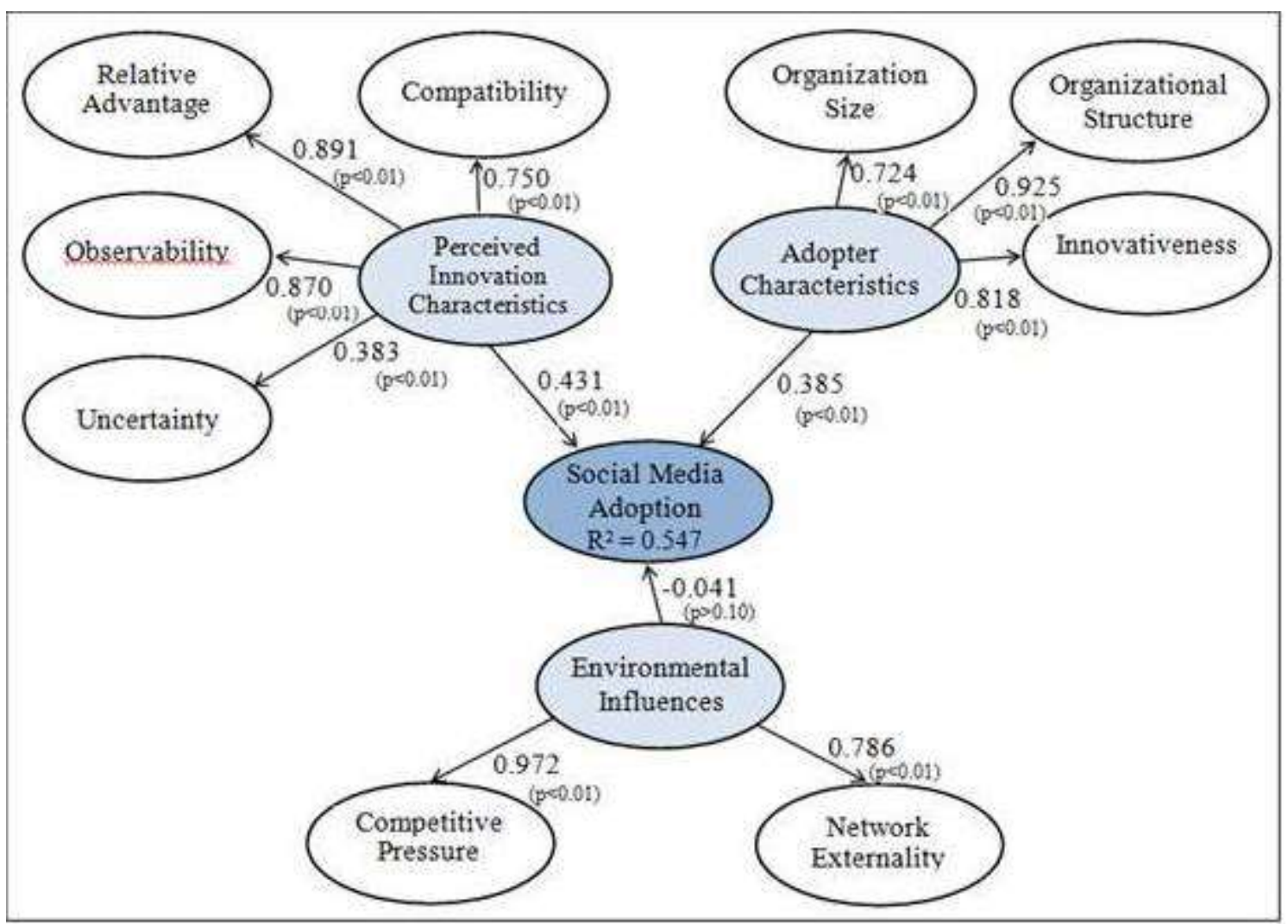

Figure 2 - Structural model of organizational social media adoption

The model was bootstrapped in accordance with the recommendations of Hair Junior et al. (2005), with the use in 200 cases with 200 repetitions (200 subsamples) to verify the Student's t-test, and the paths presented in Table 5 were thus analyzed. This analysis allowed us to observe that the paths' t-test results indicated that the relationship between environmental influences and social media adoption showed no significant result $(\mathrm{p}>10 \%)$ and is thus considered unsupported.

Table 5 - Bootstrapping Analysis of the Paths

\begin{tabular}{|c|c|c|c|c|c|c|}
\hline Paths & $\begin{array}{c}\text { Original } \\
\text { sample }\end{array}$ & $\begin{array}{c}\text { Mean of } \\
\text { bootstrapping } \\
\text { samples }\end{array}$ & $\begin{array}{l}\text { Standard } \\
\text { deviation }\end{array}$ & $\begin{array}{c}\text { Standard } \\
\text { error }\end{array}$ & t-test & Significance \\
\hline Adopter Char. $\rightarrow$ Organization Size & 0.724 & 0.728 & 0.031 & 0.031 & 23.127 & $\mathrm{p}<0.01$ \\
\hline Adopter Char. $\rightarrow$ Organizational Structure & 0.925 & 0.927 & 0.011 & 0.011 & 83.935 & $\mathrm{p}<0.01$ \\
\hline Adopter Char. $\rightarrow$ Org. Disp. Innovativeness & 0.818 & 0.822 & 0.023 & 0.023 & 35.525 & $\mathrm{p}<0.01$ \\
\hline Adopter Char. $\rightarrow$ Social Media Adoption & 0.385 & 0.373 & 0.090 & 0.090 & 4.270 & $\mathrm{p}<0.01$ \\
\hline Perc. Innov. Char. $\rightarrow$ Uncertainty & 0.383 & 0.398 & 0.072 & 0.072 & 5.305 & $\mathrm{p}<0.01$ \\
\hline Perc. Innov. Char. $\rightarrow$ Observability & 0.870 & 0.873 & 0.014 & 0.014 & 62.978 & $\mathrm{p}<0.01$ \\
\hline Perc. Innov. Char. $\rightarrow$ Relative Advantage & 0.891 & 0.892 & 0.015 & 0.015 & 59.027 & $\mathrm{p}<0.01$ \\
\hline Perc. Innov. Char. $\rightarrow$ Compatibility & 0.750 & 0.744 & 0.039 & 0.039 & 19.406 & $\mathrm{p}<0.01$ \\
\hline Perc. Innov. Char. $\rightarrow$ Social Media Adoption & 0.433 & 0.449 & 0.116 & 0.116 & 3.748 & $\mathrm{p}<0.01$ \\
\hline Environmental Infl $\rightarrow$ Competitive Pressures & 0.972 & 0.973 & 0.004 & 0.004 & 281.647 & $\mathrm{p}<0.01$ \\
\hline Environmental Infl. $\rightarrow$ Network Externalities & 0.786 & 0.791 & 0.039 & 0.039 & 20.232 & $\mathrm{p}<0.01$ \\
\hline Environmental Infl $\rightarrow$ Social Media Adoption & -0.041 & -0.048 & 0.066 & 0.066 & 0.620 & n.s. \\
\hline
\end{tabular}

Note: Critical values for $t$ (199g.l.): $\mathrm{p}<20 \%=0.843 ; \mathrm{p}<10 \%=1.653 ; \mathrm{p}<5 \%=1.972 ; \mathrm{p}<2 \%=2.186$ and $\mathrm{p}<$ $1 \%=2.601$ 
Given the significance of the paths tested during the structural modeling, the positive relationship between perceived characteristics of innovation and characteristics of the adopter with the social media adoption was evident. The relationship between environmental influences and social media adoption, for which the path was not significant, was not found to be positive.

The hypothesis 1 , the relationship between perceived innovation characteristics and organizational social media adoption, was supported corroborating the results of studies conducted by Rogers (1983), Moore and Benbasat (1991) and Frambach and Schillewaert (2002).

Among the factors that make up the construct "perceived innovation characteristics", we identified that "Relative advantage" was identified as the main factor. This result confirmed the claims of Tan and Thoen (2001), Teo and Pok (2003) and Papiers and Clement (2008): relative advantage is an important factor in the adoption of technology based innovations, since the benefits resulting from social media adoption in business processes leads to their extensive use in the organization.

The observability of social media use also made an important contribution to the identification of perceived innovation characteristics, confirming the suggestion by Rogers (1983) and Frambach and Schillewaert (2002) that the visibility of the results of an innovation encourages adoption.

Compatibility contributed significantly to perceived innovation characteristics, demonstrating the consistency of social media use with the companies' values and needs. Compatibility is thus interpreted as familiar in corporate business processes (ILIE et al., 2005).

Uncertainties exhibited a moderate but significant positive contribution to perceived innovation characteristics, demonstrating that technical, financial and social issues, although an important influence on the decision to adopt an innovation (FRAMBACH; SCHILLEWAERT, 2002), have little relevance to social media adoption. This may occur because social media have been extensively tested by the general public to maintain personal and professional relationships (SAFKO, 2010), proving to be a tool that is technologically easy to use (BHAGAT et al., 2009), requires no great financial investments for daily use and does not promote the creation of conflicts in the adopter's organizational environment. 
Hypothesis 2, the relationship between adopter characteristics and social media adoption was confirmed, aligning with the results communicated in works by Rogers (1983), Tornatzky and Fleisher (1990) and Frambach and Schillewaert (2002).

Among the constructs that form the variable "adopter characteristics", "Organization size" contributed significantly, confirming what Rogers (1983), Damounpour (1996), OECD (2012) and Zhu, Kraemer and $\mathrm{Xu}$ (2006) indicated: larger companies have a greater propensity to adopt innovations than smaller firm does. However, it is interesting to note that the report of the OECD (2012) found that large firms are more likely to adopt e-commerce (considered an innovation) than small firms, but do not necessarily use it more intensively.

Organizational structure presented a strong positive influence on the characteristics of social media adopters. Thus, the survey data point to companies with strong evidence of structural complexity and moderate structural formalism. These characteristics contribute to social media adoption because they are tools that enhance relationships and facilitate communication among users (SAFKO, 2010), contributing to the reduction of the organizational structure's complexity in an informal way.

The companies studied showed strong organizational disposition innovativeness, contributing significantly to the identification of characteristics of adopters and thus corroborating the relationship presented by Frambach and Schillewaert (2002).

Regarding to the hypothesis 3, we didn't find a significant relationship between environmental influences and social media adoption. The data show that environmental influences do not exert positive influence on the social media adoption and that the relationship is not supported due to significance level( $\mathrm{p}>0.10)$ as indicated in figure 2; so, hypothesis 10 was not supported.

Tornatzky and Fleischer (1990) and Frambach and Schillewaert (2002) indicate that environmental influences have an important role in the decision to adopt innovations. However, the result obtained in this study revealed that in the case of social media, environmental influences (identified by competitive pressure and network externality) do not affect degree of innovation adoption.

According to Balasubramanian and Mahajan (2001), user interaction in social media has a focus that is understood by both parties, who have a common interest or goal. Thus, we conclude that once a connection has been established between social media actors, environmental influences, which are important to the adoption decision, lose strength and no 
longer influence companies' use of innovations. Nevertheless, this is a relation to be tested in other future studies.

In the sample studied, competitive pressures and network externalities were identified as having a strong positive effect on characteristics of environmental influences on social media adoption, confirming both what Frambach and Schillewaert posit in their Multi-level Model for Innovation Adoption (2002).

Having discussed the significance of the paths tested and the support (or not, in three cases) of the hypotheses suggested to test the proposed model, the study's theoretical model is shown to be robust, representing a real situation with regard to the proposed analysis. This weighting is demonstrated in the ability of the model's proposed relationships to reveal important aspects influencing organizational social media adoption.

\section{FINAL CONSIDERATIONS}

This study sought to contribute to the innovation acceptance theory by proposing and testing a theoretical model to assess organizational social media adoption, understood as an organizational innovation.

The results obtained from the analysis of the proposed model showed that the constructs produced confidence indices consistent with the recommended standards. The test of the model, based on the total sample, showed that the constructs preceding social media adoption explained approximately 55\% of the last construct's variance and that this proportion was consistent with the average for innovation adoption studies.

Of the three hypotheses proposed, two were supported. The hypothesis related to environmental influences as determining factors in organizational social media adoption was not supported, by reasons proposed in the previous section.

The validation of the study's theoretical model presented evidence that after the decision to adopt innovations, such as the use of social media, perceived innovation characteristics are a major influence on the continuity and intensity of the innovation's use. They have a strong influence because of the relative advantages acquired (the most important variable), the effective observability of results obtained from this adoption and the innovation's compatibility with the company's environment and needs, confirming the relationships presented by Frambach and Schillewaert (2002). Conversely, uncertainties related to the adoption decision are diluted by the innovation's use, diminishing its importance to the determination of innovation adoption. 
Adopter characteristics also have a direct influence on innovation adoption, confirming what is posited in the literature: larger companies utilize social media more intensively, and the adopter's organizational disposition innovativeness strongly influences the continuity and intensity of the innovation's use. Organizational structure, identified in the literature (CALANTONE et al., 2002; FRAMBACH; SCHILLEWAERT, 2002; HULT et al., 2002; CHEN; CHANG, 2012) as a negative influence on the innovation adoption decision, was presented as a positive influence on the social media adoption decision in our study. This result was obtained because the companies studied have strong evidence of structural complexity and moderate structural formalism. This complexity and formalism contributes to the use of social media in business processes, as it enhanced relationships and facilitates communication among users, contributing to the reduction of the organizational structure's complexity in an informal way.

Environmental influences, identified by Tornatzky and Fleischer (1990) and Frambach and Schillewaert (2002) as determinants of the decision to adopt innovations, were not confirmed to determine the degree of adoption. Rather, following the adoption of social media, environmental influences (identified by competitive pressures and network externalities) do not affect the degree of the social media adoption, leaving only perceived social media characteristics and adopter characteristics to influence the continuity and intensity of the social media's use.

As social media is still a recent technological resource, the literature on social media is limited. Most of the texts are concerned with the management or administration of Internetrelated technology. Of the articles and books addressing this subject, few are the results of scientifically rigorous studies conducted in Brazil. Therefore, addressing corporate social media adoption through an understanding of the factors determining its adoption is important to the expansion of knowledge in this area in the Brazilian scenario.

Even around the world, the most papers about social media adoption are related to individual social media adoption (CURTIS et al., 2010; EYRICH, 2008). Analyzing Web of Science database, for example, we can find that research about organizational social media adoption rely on qualitative studies or use of individual acceptance models (like UTAUT or TAM) applied to organizations (MERGEL, 2013; HONG, 2012; THACKERAY et al., 2012).

In this context, as a contribution to science, this work provides a quantitative analysis of the factors influencing companies concerning social media adoption. The models of organizational innovation adoption proposed by Rogers (1983), Tornatzky and Fleischer 
(1990), Venkatesh et al. (2003) and Frambach and Schillewaert (2002), used as a foundation for the development of this work, only address the qualitative aspects of the decision to adopt innovations. It is important to determine the quantitative factors influencing the effective use of this innovation and developing scales that could be used in future studies. In this sense, the scales used in this research were tested and validated, allowing its use in future research.

In terms of managerial contributions, the analysis of the causal relationships between the variables involved contributes to the understanding and control of social media adoption and use, corresponding with companies' expectations regarding the achievement of results.

This study, therefore, may be useful as a theoretical foundation for those wishing to supplement their virtual operations. The study aims to reduce unnecessary costs and conflicts, which would most likely be present in the case of purely intuitive attempts at adopting these tools.

The use of social media in business processes is still developing within companies. Thus, the ability to develop such a complex process imposes limitations that serve as barriers to be overcome in future investigations.

In terms of study limitations, the first one is the difficulty of collecting survey data. It was difficult to obtain consistent answers from completed questionnaires because of the time factor and the availability of respondents. Over 700 companies using social media were contacted about completing the questionnaires, and in many cases, those responsible for the use of these tools in the companies refused to respond because the business confidentiality of the information was being collected. Other limitation is the type of social media use occurring in companies. The presence of a company page on a social media site characterizes the company as an adopter but does not reflect actual use. Various micro and small businesses surveyed have social media pages and provide links to institutional information on social media but do not update this information or interact with the people consulting them. The main goal of social media developers is interaction between individuals or corporations.

Another limitation refers to the dependent variable of social media adoption. We used a count of departments that have adopted social media as a proxy indicator for adoption. However, there is the possibility that one firm may use social media in three departments, but is not a heavy social media user as another firm only uses it in marketing, but uses it intensively. Therefore, the estimation of "extensively" (as we asked in our questionnaire) as a way of measuring the adoption degree is subjective and will vary from respondent to 
respondent. We also could include the fact that this was a cross sectional study as another limitation.

Despite the limitations mentioned above, the study provided relevant information on the determining factors in corporate social media adoption and could be a foundation for further research on the subject.

The following can be suggested for future studies:

-The application of this research in economic sectors or specific geographic locations where the organizational or social culture variable of the segment could be considered a determining factor in corporate social media adoption

-The development of works that seek to assess qualitative and quantitative results achieved by companies through the adoption of social media for their business processes and the influence of these results on the continuity or intensity of these media's use.

-Verify the influence of variables that were not significant in this study in future studies in other countries, as environment for example.

\section{CONTRIBUTIONS BY THE AUTHORS}

José Braz de Araújo contributed to the development of research.

Silvia Novaes Zilber supervised the thesis that originated article.

\section{REFERENCES}

AJZEN, I. The theory of planned behavior. Organizational Behavior and Human Decision Processes, v. 50, n. 2, p. 179-211, 1991.

BALASUBRAMANIAN, S.; MAHAJAN, V. The economic leverage of the virtual community. International Journal of Electronic Commerce, v. 5, n. 3, p. 103-138, 2001.

BHAGAT, P. S.; KLEIN, A.; SHARMA, V. The impact of new media on internet-based group consumer behavior. Journal of Academy of Business and Economics, v. 9, n. 3, p. 83-94, 2009.

BNDES. Banco Nacional de Desenvolvimento. MSMEs primer. 2011. Disponível em: <http://www.bndes.gov.br/SiteBNDES/export/sites/default/bndes_pt/Navegacao_Suplementar /Perfil/Micro_Pequena_e_Media_Empresa_e_Pessoa_Fisica/cartilha_MPME.pdf $>$. Acesso em: 14 jun. 2012.

BOYD, D. M.; ELLISON, N. B. Social network sites: definition, history, and scholarship. Journal of Computer-Mediated Communication, v. 13, n. 1, p. 210-230, 2008.

BRYNJOLFSSON, E. The four ways IT is revolutionizing innovation. MIT Sloan Management Review, p.75-80, 2011. 
CALANTONE, R. J.; CAVUSGIL, S. T.; ZHAO, Y. Learning orientation, firm innovation capability and firm performance. Industrial Marketing Management, v. 31, n. 6, p. 515$524,2002$.

CARAYANNIS, E. G.; PROVANCE, M. Measuring firm innovativeness: toward a composite innovation index built on firm innovative posture, propensity and performance attributes. International Journal of innovation and Regional Development, v. 1, n. 1, p. 90-107, 2008.

CASTILLO, C.; MENDOZA, M.; POBLETE, B. Predicting information credibility in timesensitive social media. Internet Research, v. 23, n. 5, p. 560-588, 2012.

CAVAZZA, F. Social media landscape. Disponível em: <www.fredcavazza.net>. Acesso em: 12 mar. 2012.

CHAUHAN, G. S. Advertising through social media networks: let's catch up with the internet audience. International Journal of Research in Computer Application \& Management, v. 1, n. 2, p. 112-114, 2011.

CHEN, S. T.; CHANG, B. G. The effects of absorptive capacity and decision speed on organizational innovation: a study of organizational structure as an antecedent variable.

Contemporary Management Research, v. 8, n. 1, p. 27-50, 2012.

CHIN, W. W. The partial least squares approach for structural equation modeling. In: MARCOULIDES, G. A. (Ed.). Modern methods for business research. London: Psychology Press, 1998. p. 295-336.

COMPEAU, D. R.; HIGGINS, C. A. Application of social cognitive theory to training for computer skills. Information Systems Research, v. 6, n. 2, p. 118-143, 1995.

COOPER, D. R. SCHINDLER, P. S. Business research methods. 7. ed. Porto Alegre: Bookman, 2005.

CULNAN, M. J.; MCHUGH, P. J.; ZUBILLAGA, J. I. How Large U.S. Companies can use Twitter and other social media to gain business value. MIS Quarterly Executive, v. 9, n. 4, p. 243-259, 2010.

CURTIS, L. E. C. et al. Adoption of social media for public relations by nonprofit organizations. Public Relations Review, v. 36, n. 1, p. 90-92, 2010.

DAFT, R. L. Administration. 6. ed. São Paulo: Thomson, 2005.

DAMANPOUR, F. Organizational complexity and innovation: developing and testing multiple contingency models. Management Science, v. 42, n. 5, p. 693-716, 1996.

DAVIS, F. D. Perceived usefulness, perceived ease of use, and user acceptance of information technology. MIS Quaterly, v. 13, n. 3, p. 319-339, 1989.

DAVIS, F. D.; BAGOZZI, R. P.; WARSHAW, P. R. Extrinsic and intrinsic motivation to use computers in the workplace. Journal of Applied Social Psychology, v. 22, n. 14, p. 1111$1132,1992$. 
DELOITTE. Social media in companies: the online relationship with the market. 2010. Disponível em: <http://www.deloitte.com/assets/Dcom-

Brazil/Local\%20Assets/Documents/Estudos\%20e\%20pesquisas/Apresentacao_MidiasSociais .pdf>. Acesso em: 03 abr. 2012.

The fastest growing SMEs in Brazil: a study on the challenges of the business environment for emerging companies. 2012. Disponível em:

$<\mathrm{http}: / /$ www.deloitte.com/assets/Dcom-

Brazil/Local\%20Assets/Documents/Estudos\%20e\%20pesquisas/PME2012.pdf >. Acesso em: 13 out. 2012.

EYRICH, N.; PADMAN, M. L.; SWEETSER, K. D. PR practitioners' use of social media tools and communication technology. Public relations review, v. 34, n. 4, p. 412-414, 2008.

EXAME. Maiores e melhores. Exame, Edição Especial. São Paulo: Abril, 2012.

FOLDEES. Site institucional. 2012. Disponível em: 〈www.foldees.com〉. Acesso em: 18 fev. 2012.

FRAMBACH, R. T.; SCHILLEWAERT, N. Organizational innovation adoption: A multilevel framework of determinants and opportunities for future research. Journal of Business Research, v. 55, p. 163-176, 2002.

FURLAN, P. Brands bet on unique campaigns for social networks. Revista Consumidor Moderno. 2012. Disponível em: <http://consumidormoderno.uol.com.br/marketing/marcasapostam-em-campanhas-exclusivas-para-as-redes-sociais>. Acesso em: 30 abr. 2012.

Gil, A. C. Como elaborar projetos de pesquisa. 4. ed. São Paulo: Atlas, 2002.

HAIR JUNIOR., J. F. et al. Análise multivariada de dados. Porto Alegre: Bookman, 2009.

HE, W.; ZHA, S.; LI, L. Social media competitive analysis and text mining: a case study in the pizza industry. International Journal of Information Management, v. 33, n. 3, p. 464472, 2013.

HONG, S. Online news on Twitter: newspapers' social media adoption and their online readership. Information Economics and Policy, v. 24, n. 1, p. 69-74, 2012.

HULT, G. T. M.; FERRELL, O. C.; HURLEY, R. F. Global organizational learning effects on cycle time performance. Journal of Business Research, v. 55, n. 5, p. 377-387, 2002.

IBGE. Instituto Brasileiro de Geografia e Estatística. Estatísticas do cadastro central de empresas 2010. 2012. Disponível em:

<http://www.ibge.gov.br/home/estatistica/economia/cadastroempresa/2010/defaulttabpdf_em presa.shtm>. Acesso em: 30 out. 2012.

ILIE, V. C. et al. Gender differences in perceptions and use communication technologies: A diffusion of innovation approach. Information Resources Management Journal, v. 18, n. 3, p. 13-31, 2005. 
JUNGHERR, A.; JÜRGENS, P. Forecasting the pulse: how deviations from regular patterns in online data can identify offline phenomena. Internet Research, v. 23, n. 5, p. 589-607, 2013.

KALAMPOKIS, E.; TAMBOURIS, E.; TARABANIS, K. Understanding the predictive power of social media. Internet Research, v. 23, n. 5, p. 544-559, 2013.

KAPLAN, A. M.; HAENLEIN, M. Users of the world, unite! The challenges and opportunities of Social Media. Business Horizons, v. 53, p. 59-68, 2010.

LUMPKIN, G. T.; DESS, G. G. Clarifying the entrepreneurial orientation construct and linking it to performance. The Academy of Management Review, v. 21, n. 1, p. 135-72, 1996.

MALHOTRA, N. Marketing research: an applied orientation. 3. ed. Porto Alegre: Bookman, 2004.

MERGEL, I. Social media adoption and resulting tactics in the US federal government. Government Information Quarterly, v. 30, n. 2, p. 123-130, 2013.

MEYER, A. D.; GÓES, J. B. Organizational assimilations of innovations: A multilevel contextual analysis. Academy of Management Journal, v. 31, n. 4, p. 897-923, 1988.

MOORE, G. C.; BENBASAT, I. Development of an instrument to measure the perceptions of adopting an information technology information. Information Systems Research, v. 2, n. 3, p. 173-191, 1991.

NGAI,E. W.T.; TAO, S. S. C.; MOON, K. K. L. Social media research: theories, constructs, and conceptual frameworks. International Journal of Information Management, v. 35, n. 1, p. 33-44, 2015. Disponível em: <http://ac.els-cdn.com/S026840121400098X/1-s2.0S026840121400098X-main.pdf?_tid=ebbbf922-7f13-11e4-914100000aacb360\&acdnat=1418068606_2a1d1ae5bde57d63112cc874757901c9>.

OECD. Oslo manual. 3. ed. Paris, FR: OECD Publishing, 2005.

OECD internet economy outlook 2012. Paris, France: OECD Publishing, 2012.

PINDYCK, R. S.; RUBINFELD, D. L. Microeconomia. 6. ed. São Paulo: Prentice Hall, 2005 .

PORTER, M. Strategy and the internet. Harvard Business Review, v. 79, n. 3, p. 63-78, 2001.

RATTEN, V.; RATTEN, H. Social cognitive theory in technological innovations. European Journal of Innovation Management, v. 10, n. 1, p. 90-108, 2007.

RATTEN, V. Behavioral intentions to adopt technological innovations: the role of trust, innovation and performance. International Journal of Enterprise Information Systems (IJEIS), v. 10, n. 3, p. 1-12, 2014.

ROGERS, E. M. Diffusion of innovations. New York: Free Press, 1983. 
SAFKO, L. The social media bible. Hoboken: John Wiley \& Sons Inc., 2010.

SANKAR, Y. Management of technological change. USA: John Wiley \& Sons, 1991.

SCHUMACKER, R. E.; LOMAX, R. G. A beginner's guide to structural equation modeling. Hillsdale, NJ: Lawrence Erlbaum Associates, 2004.

SHAO, G. Understanding the appeal of user-generated media: a uses and gratification perspective. Internet Research, v. 19, n. 1, p. 7-25, 2009.

THACKERAY, R. et al. Adoption and use of social media among public health departments. BMC Public Health, v. 12, n. 1, p. 242, 2012.

TAN, Y. H.; THOEN, W. Toward a generic model of trust for electronic commerce. International Journal of Electronic Markets, v. 5, n. 2, p. 61-74, 2001.

TAPSCOTT, D.; WILLIAMS, A. D. Wikinomics. Rio de Janeiro: Nova Fronteira, 2007.

TAYLOR, S.; TODD, P. A. Understanding information technology usage: a test of competing models. Information Systems Research, v. 6, n. 4, p. 144-176, 1995.

TEO, T. S. H.; POK, S. H. Adoption of WAP-enabled mobile phones among Internet users. The International Journal of Management Science, v. 31, n. 6, p. 483-498, 2003.

THOMPSON, R. L.; HIGGINS, C. A.; HOWELL, J. M. Personal computing: toward a conceptual model of utilization. MIS Quaterly, v. 15, n. 1, p. 124-143, 1991.

TIDD, J.; BESSANT, J.; PAVITT, K. Innovation management. Porto Alegre: Bookman, 2008.

TORNATZKY, L. G.; FLEISCHER, M. The processes of technological innovation. Lexington: Lexington Books, 1990.

TURBAN, E.; MCLEAN, E.; WETHERBE, J. Information technology for management. Porto Alegre: Bookman, 2004.

VENKATESH, V.; DAVIS, F. A theoretical extension of the technology acceptance model: Four longitudinal field studies. Management Science, v. 46, n. 2, p. 186-204, 2000.

VENKATESH, V. et al. User acceptance of information technology: toward a unified view. MIS Quarterly, v. 27, n. 3, p. 425-478, 2003.

VENKATESH, V.; THONG, J. Y. L.; XU, X. Consumer acceptance and use of information technology: extending the unified theory of acceptance and use of technology. MIS Quarterly, v. 36, n. 1, p. 157-178, 2012.

ZHU, K. Information transparency of business-to-business electronic markets: a gametheoretic analysis. Management Science, v. 50, n. 5, p. 670-685, 2004.

ZHU, K.; KRAEMER, K. L.; XU, S. The process of innovation assimilation by firms in different countries: a technology diffusion perspective on e-business. Management Science, v. 52, n. 10, p. 1557-1576, 2006. 